\title{
The general public's perceptions and use of antimicrobials in Trinidad and Tobago
}

\author{
Neeta Parimi, ${ }^{1}$ Lexley M. Pinto Pereira, ${ }^{2}$ and Parimi Prabhakar ${ }^{3}$
}

ABSTRACT Objective. To determine the general public's perceptions and use of antibiotics in Trinidad and Tobago, a two-island republic in the Caribbean.

Methods. This prospective study surveyed 824 randomly selected households listed in the telephone directory, from November 1998 to January 1999. Through telephone interviews we determined knowledge about antibiotics and beliefs concerning their safety and efficacy. We studied the influence of age, gender, education, and having private health insurance on knowledge, self-medication, storing medication at home for emergency use ("hoarding"), and asking a private doctor to prescribe antibiotics ("demand prescribing").

Results. For the 824 telephone calls that the interviewers completed, 753 of the households agreed to participate (91.4\% response rate). Of those 753 participants, 699 of them (93\%) knew the term "antibiotic," 29\% (206/699) said it was a drug for bacterial infections, and 25\% (170/690) had asked a doctor for an antibiotic prescription. Penicillin was correctly identified as an antibiotic across age, gender, and education categories, but $36 \%$ of respondents incorrectly said Benadryl (diphenhydramine), a common over-the-counter cough and cold formulation, was an antibiotic. Gender was not significantly associated with knowledge of antibiotic safety, with self-medication, or with hoarding antibiotics. On the other hand, completion of tertiary (university) education was significantly associated with correct knowledge of the safety of antibiotics and whether or not they could cure all infections. Of the various antimicrobials, beta-lactams were the ones that survey respondents had used most frequently in the preceding year, and $20 \%$ of antibiotics users had used multiple antibiotics in that period. In comparison to persons with private health insurance, more individuals without private health insurance said that antibiotics are safe and do not have side effects, and more of them also incorrectly called aspirin and Benadryl antibiotics.

Conclusions. In Trinidad and Tobago, inappropriate use of antimicrobials results from self-medication, over-the-counter availability at the community pharmacy, prescribing on demand, and lack of regulatory control. In order to contain antibiotic abuse, both the Drug Inspectorate of the Ministry of Health and the Pharmacy Board should exert stricter control on the dispensing of antibiotics at private pharmacies. Further, education of the general public and of health care professionals on antibiotic misuse and appropriate use must be instituted, along with community-based surveillance of antimicrobial resistance trends.

Key words Antimicrobials, health education, professional education, self-medication, Caribbean.

1 Bishop Anstey High School, Port-of-Spain, Trinidad and Tobago.

2 University of the West Indies, Faculty of Medical Sciences, Department of Paraclinical Sciences, St. Augustine, Trinidad and Tobago. Send correspondence to: Lexley M. Pinto Pereira, Faculty of Medi- cal Sciences, University of the West Indies, St. Augustine, Trinidad, West Indies; e-mail: lexleyp@ hotmail.com

3 Caribbean Epidemiology Center (Pan American Health Organization/World Health Organization), Port-of-Spain, Trinidad and Tobago.
Bacterial resistance to multiple antibiotics is a growing global problem, due in large measure to extensive and inappropriate usage of antibiotics (1, 2). That resistance occurs in hospitals 
and their intensive care units and increasingly in the community setting as well.

Antibiotic resistance may be more widespread in lesser-developed countries, where there are fewer controls on the use of antimicrobial drugs (3) and where the higher incidence of infectious disease in the population fuels the demands for the drugs (4). In developing countries such major community pathogens as Neisseria gonorrhoea, Streptococcus pneumoniae, Salmonella typhi, and Shigella spp. have already demonstrated their resistance to the first-line, less-expensive broadspectrum antimicrobials (5-8). Gramnegative pathogens that cause hospital-acquired infections have developed resistance to extended-spectrum betalactam antimicrobials, which until recently demonstrated high cure rates for these infections $(9,10)$.

In the English-speaking Caribbean, infections due to resistant pathogens are frequent in hospitals and also occur in the family practice setting. The reported rates of penicillin-resistant pneumococci and chloramphenicolresistant Haemophilus influenzae in the English- and Dutch-speaking Caribbean are low, but high rates of resistance to ampicillin, co-trimoxazole, and gentamicin by common gram-negative pathogens that cause urinary tract infections have been reported (11).

Various factors contribute to this resistance problem in developing countries around the world (3). These include indiscriminate and widespread use of antimicrobials for communityacquired infections, self-medication, incomplete treatment courses, and the unregulated use of antibacterial drugs. Antibiotic use without physician consultation occurs not only in developing nations but also in the United States of America (12). In the United Kingdom, concerns have been raised regarding deregulation and shifting antimicrobials for topical or oral use from the "prescription-only medicine" status (to be dispensed only on a physician's prescription) to the "pharmacy medicine" category (pharmacists can dispense without a prescription) (13).
This study was undertaken to examine how the public at large in Trinidad and Tobago perceives and uses antibiotics. Trinidad and Tobago is a two-island Caribbean republic of 1.3 million people. It is located just off the coast of Venezuela, and it is the second-largest country in the Englishspeaking Caribbean. Divided into 8 counties, Trinidad has some $96 \%$ of the country's population, with $46 \%$ of those persons living in urban areas (Tobago is classified as a ward). Trinidad and Tobago has a literacy rate above $90 \%$, and at least $75 \%$ of the country's adult population has completed secondary school.

Medical care in Trinidad and Tobago is available free through public sector health care facilities. At these centers, patients can consult specialist physicians, undergo recommended investigations and procedures, and receive prescribed medication from the country's restricted drug list, all at no cost. Other than these centers, there are no free pharmacies. At these public centers, however, patients often encounter long waiting periods and find that drugs are available erratically or not at all. To receive expeditious advice and treatment, many patients consult a private doctor at their own expense, and that cost may be covered by private health insurance. Patients can also go to a private pharmacy and directly approach the pharmacist for advice and treatment. Talking to the pharmacist has the advantage of avoiding doctor consultation fees, and much of the population utilizes this approach.

The country's Food and Drugs Act classifies antibiotics as controlled drugs, to be dispensed only with a prescription. An anomaly in the law is its strict application only to those drugs defined by the term "antibiotics" per se and not to all antimicrobials; therefore, agents such as co-trimoxazole and the quinolones, which do not fall under this regulation, are available without prescription. Nevertheless, it is widely known that antimicrobial agents can be obtained at pharmacies without a prescription, and pharmacists simply dispense these drugs as over-the-counter medications in response to requests from customers.

Prior to this study, no data had been available on the general public's perceptions and use of antibiotics in the English-speaking Caribbean.

\section{METHODS}

\section{Study design}

We conducted a cross-sectional population-based study in Trinidad and Tobago by interviewing study subjects over the telephone. We calculated a sample size of 800 households with a working telephone, based on $80 \%$ power to detect a difference of at least 3\% in perception and use of antibiotics, given an alpha of 0.05. As we did not know in advance what the telephone-survey participation rate would be for answered calls nor the number of busy or unanswered calls, we selected 1600 households at random from the listed 167272 households in the telephone directory of the Telecommunication Services of Trinidad and Tobago. It is estimated that about $90 \%$ of households in the country have telephones and that about $15 \%$ of those customers have an unlisted telephone number.

\section{Interview}

Six interviewers were trained to conduct structured interviews over the telephone. Prior to interviewing members of the general public, the interviewers practiced administering the questionnaire, to be certain that they were conveying identical meanings for the questions. The interviewers rehearsed with each other and also with some adult friends and relatives, both face-to-face and on the telephone. Based on that pilot-testing experience, the survey instrument was modified.

With the general public, the questionnaire was administered to a responsible adult household member who was at least 18 years old and who had to take care of family members 
when they were ill. The objective of the study and its format were explained to participants at the start of the interview. When persons refused to participate in the study, the interviewer asked if there was any specific reason for not complying, and recorded any reason that was given. Respondents who said they knew the term "antibiotic" were asked to explain their understanding of it, and those who had not heard the term were offered the following explanation: "Antibiotics are drugs that are prescribed for the treatment of diseases caused by germs."

Respondents were asked to identify antibiotics from a presented list of common drugs and also to answer questions on antibiotic safety, curative properties, possible common infectious conditions among household members, and any relevant action taken in those situations. Information was also obtained, for both adult and child patients, concerning storage of antibiotics at home for emergency use ("hoarding"); consulting a private sector physician for a fee; "prescribing on demand" for antibiotics, that is, with a doctor providing a prescription in response to a request from a patient; and self-medication. If antibiotics were consumed, participants were asked if they complied with all recommended instructions, and whether they shared these drugs with other family members or with friends.

In instances where individuals did not answer questions, the questions were repeated in order to prompt an answer. If the persons still failed to answer, that was classed as "no response."

\section{Data analysis}

Data were entered and analyzed using the Epi Info version 6.04 software program (Centers for Disease Control and Prevention, Atlanta, Georgia, United States). The chi-square test (Mantel-Haenszel test and Fisher's exact test) was used to compare categorical variables. Student $t$ test analysis was used to compare the means of continuous data. Analyses for the li-

TABLE 1. Demographic characteristics of survey respondents in study of the general public's perceptions and use of antibiotics, Trinidad and Tobago, 1998-1999a

\begin{tabular}{lcc}
\hline \multicolumn{1}{c}{ Characteristic } & No. & $\%$ \\
\hline Gender & & \\
$\quad$ Male & 248 & 33 \\
Female & 495 & 67 \\
Age (years) & & \\
$18-30$ & 199 & 27 \\
$31-40$ & 235 & 32 \\
$41-50$ & 137 & 19 \\
$\geq 51$ & 156 & 21 \\
Refused & 12 & 2 \\
Highest educational level completed & & 20 \\
Primary school & 137 & 56 \\
Secondary school & 385 & 24 \\
Tertiary institution & 161 & \\
Employment status & & 49 \\
Employed for wages & 325 & 15 \\
Self-employed & 98 & 18 \\
Housewife & 121 & 18 \\
Retired or unemployed & 123 & \\
Private health insurance & & 28 \\
Have private health insurance & 202 & 72 \\
No private health insurance & 532 & \\
\hline
\end{tabular}

a The total number of participants was $824 ; 753$ of them (91.4\%) agreed to participate in the survey; the figures in the table omit missing data (e.g., no answer was given).

near trend in proportions were done by chi-square for trend using the STATCALC function in the Epi Info software.

\section{RESULTS}

Out of 950 calls that the interviewers made, they received a busy signal or no answer in 126 of the cases, resulting in a sample of 824 respondents. Of those 824 persons, 753 agreed to participate, for a $91.4 \%$ response rate. Although the 753 was $5.9 \%$ less than the original projected sample size of 800 , an analysis showed that the small deficit did not alter the power of the study. The main reasons that persons gave for declining to participate were a lack of interest in the interview or being too busy to answer the questions. In the eight counties of Trinidad and in the ward of Tobago the respondent participation rates ranged from $78 \%$ to $100 \%$.

Table 1 shows the demographic characteristics of the survey respondents. All the demographic data were not available for all 753 survey par- ticipants; participants for whom particular data were not available are omitted from the respective descriptions shown in Table 1.

Among the survey participants there was a higher female than male representation, $67 \%$ vs. $33 \%$. The age of the respondents ranged from 18 to 85 years, with $21 \%$ being $\geq 51$ years of age. Of the survey participants for whom the respective demographic information was available, 49\% (325/ 667) had salaried employee status and $56 \%(385 / 683)$ had completed secondary education.

\section{Knowledge and use of antibiotics}

Of the 753 persons participating in the study, 699 of them (93\%) had heard of the term "antibiotic." Of those 699 persons, 193 respondents $(28 \%)$ provided a nonspecific description such as "something the doctor tells you to buy," leaving a total of 506 persons who offered a more-specific explanation for the term antibiotic. Out of those 506, 455 persons provided a definition of the term, which we 
grouped into the following categories: a drug for bacterial infections (206 responses), just a drug (138), a drug prescribed by the doctor (58), a drug for virus/cold (31), and a drug for pain, fever, or stimulating antibodies (22).

The knowledge and use of antibiotics was analyzed using the number of participants who had heard of the term "antibiotics," which was 699. Below we first present information on the overall knowledge and use of antibiotics; later we will present similar information for the various demographic subgroups of the respondents who had heard of the term "antibiotics" and who provided an answer to the respective question.

Knowledge was assessed based on the list of common drugs that the telephone interviewers presented to the participants. Penicillin was correctly identified as an antibiotic by $83 \%$ of the respondents, while $80 \%$ could correctly identify tetracycline, and $78 \%$ could do that for Augmentin (amoxicillin/clavulanic acid). Ten percent of the respondents incorrectly said that
Tylenol (paracetamol, acetaminophen) was an antibiotic, and 9\% did that for aspirin, 36\% made that mistake for Benadryl (diphenhydramine), a common over-the-counter cough and cold formulation.

Of the participants answering the question, $24 \%$ of them said they believed that antibiotics could cure all infections. Fifteen percent of responding participants felt all antibiotics are safe, and only $12 \%$ of respondents said that antibiotics were free from side effects. Twenty-one percent of responding participants said that they hoarded antibiotics, storing them at home for emergency purposes.

Based on recall, $31 \%$ of households (220 of 699) said they had used an antibiotic during the past year, and $20 \%$ of those people (44 of 220) had used more than one antibiotic in that period. The beta-lactams were the most frequently used antibiotics, and amoxicillin was consumed by 37\% (81 of 220) of users. The penicillins were used more frequently than the cephalosporins, $7 \%$ (15 of 220$)$ vs. $4 \%$ (8 of 220$)$, respecti- vely. Among the cephalosporins, only Ceclor (cephalothin) and Zinnat (cefuroxime) had been used.

Out of the 699 respondents, 136 of them $(19 \%)$ reported they self-medicated with antibiotics obtained from private pharmacies, without a doctor's prescription. Out of 690 persons, 170 of them (25\%) admitted to demanding a prescription, that is, asking a doctor to provide a prescription even if the physician felt the antibiotic was unnecessary. Although 74\% (520 of 699) of the people said they did not share antibiotics with family and/or friends, $17 \%$ (122 of 699 ) refused to answer this question.

Table 2 and Table 3 provide details on antibiotic knowledge and use for the various demographic groupings included in the survey. The numbers of respondents shown in those two tables differ from the demographic groupings shown in Table 1 because some respondents did not answer all the questions on knowledge or use and/or because information for those who did answer was not available on

TABLE 2. Demographic variables associated with antibiotic identification in study of the general public's perceptions and use of antibiotics, Trinidad and Tobago, 1998-1999a

\begin{tabular}{|c|c|c|c|c|c|c|c|c|c|c|c|c|c|c|c|c|c|c|}
\hline \multirow[b]{3}{*}{ Variable } & \multicolumn{18}{|c|}{ Drugs that respondents said were antibiotics } \\
\hline & \multicolumn{3}{|c|}{ Penicillin } & \multicolumn{3}{|c|}{ Tetracycline } & \multicolumn{3}{|c|}{ Augmentin } & \multicolumn{3}{|c|}{ Benadryl } & \multicolumn{3}{|c|}{ Aspirin } & \multicolumn{3}{|c|}{ Tylenol } \\
\hline & $n$ & No. & $\%$ & $n$ & No. & $\%$ & $n$ & No. & $\%$ & $n$ & No. & $\%$ & $n$ & No. & $\%$ & $n$ & No. & $\%$ \\
\hline \multicolumn{19}{|l|}{ Gender } \\
\hline Male & 180 & 146 & 81 & 105 & 83 & 79 & 102 & 80 & 78 & 156 & 58 & 37 & 177 & 16 & 9 & 185 & 24 & 13 \\
\hline Female & 386 & 321 & 83 & 238 & 193 & 81 & 212 & 164 & 77 & 346 & 121 & 35 & 400 & 36 & 9 & 400 & 32 & 8 \\
\hline \multicolumn{19}{|l|}{ Age } \\
\hline 18-30 & 145 & 109 & 75 & 92 & 68 & 74 & 87 & 67 & 77 & 120 & 53 & 44 & 154 & 17 & 11 & 156 & 25 & 16 \\
\hline $31-40$ & 191 & 155 & 81 & 122 & 105 & 86 & 122 & 95 & 78 & 174 & 66 & 38 & 183 & 11 & $6^{b, c}$ & 200 & 10 & $5^{b, c}$ \\
\hline $41-50$ & 114 & 103 & $90^{d}$ & 64 & 56 & 88 & 56 & 45 & 80 & 100 & 27 & 27 & 120 & 6 & $5^{b, c}$ & 117 & 7 & $6^{b, c}$ \\
\hline$\geq 51$ & 106 & 93 & 88 & 58 & 41 & 71 & 55 & 33 & 60 & 230 & 30 & $13^{b}$ & 107 & 16 & 15 & 109 & 12 & 11 \\
\hline \multicolumn{19}{|c|}{$\begin{array}{l}\text { Highest education } \\
\text { completed }\end{array}$} \\
\hline Primary & 113 & 89 & 79 & 52 & 33 & 64 & 51 & 25 & 49 & 58 & 23 & 40 & 121 & 17 & 14 & 115 & 15 & 13 \\
\hline Secondary & 290 & 235 & 81 & 191 & 157 & 82 & 176 & 139 & 79 & 192 & 73 & 38 & 325 & 26 & 8 & 318 & 35 & 11 \\
\hline Tertiary & 137 & 125 & $91^{b}$ & 93 & 79 & $85^{b}$ & 77 & 69 & $90^{b}$ & 81 & 17 & $21^{b}$ & 150 & 6 & $4^{b}$ & 133 & 4 & $3^{b}$ \\
\hline \multicolumn{19}{|l|}{$\begin{array}{l}\text { Private health } \\
\text { insurance }\end{array}$} \\
\hline Have & 165 & 137 & 83 & 104 & 94 & $90^{\mathrm{b}}$ & 99 & 81 & 82 & 148 & 43 & 29 & 175 & 7 & 4 & 171 & 12 & 7 \\
\hline Don't have & 374 & 314 & 84 & 219 & 164 & 75 & 203 & 148 & 73 & 315 & 123 & $39^{d}$ & 380 & 38 & $10^{d}$ & 411 & 37 & 9 \\
\hline
\end{tabular}

a This table shows the demographic variables for the respondents who said that the respective drug was an antibiotic. The total numbers of persons in the various groups differ from the ones in Table 1 since the respondents who refused to answer or who did not know were excluded in this analysis.

${ }^{b}$ Chi-square test, $0.01<P<0.05$.

${ }^{c}$ Chi-square test was significant when comparing $18-30$ years versus $31-40$ and $41-50$ years.

${ }^{d}$ Chi-square test, $P<0.01$. 
TABLE 3. Sociodemographic variables associated with antibiotic knowledge, self-medication, and hoarding in study of the general public's perceptions and use of antibiotics, Trinidad and Tobago, 1998-1999a

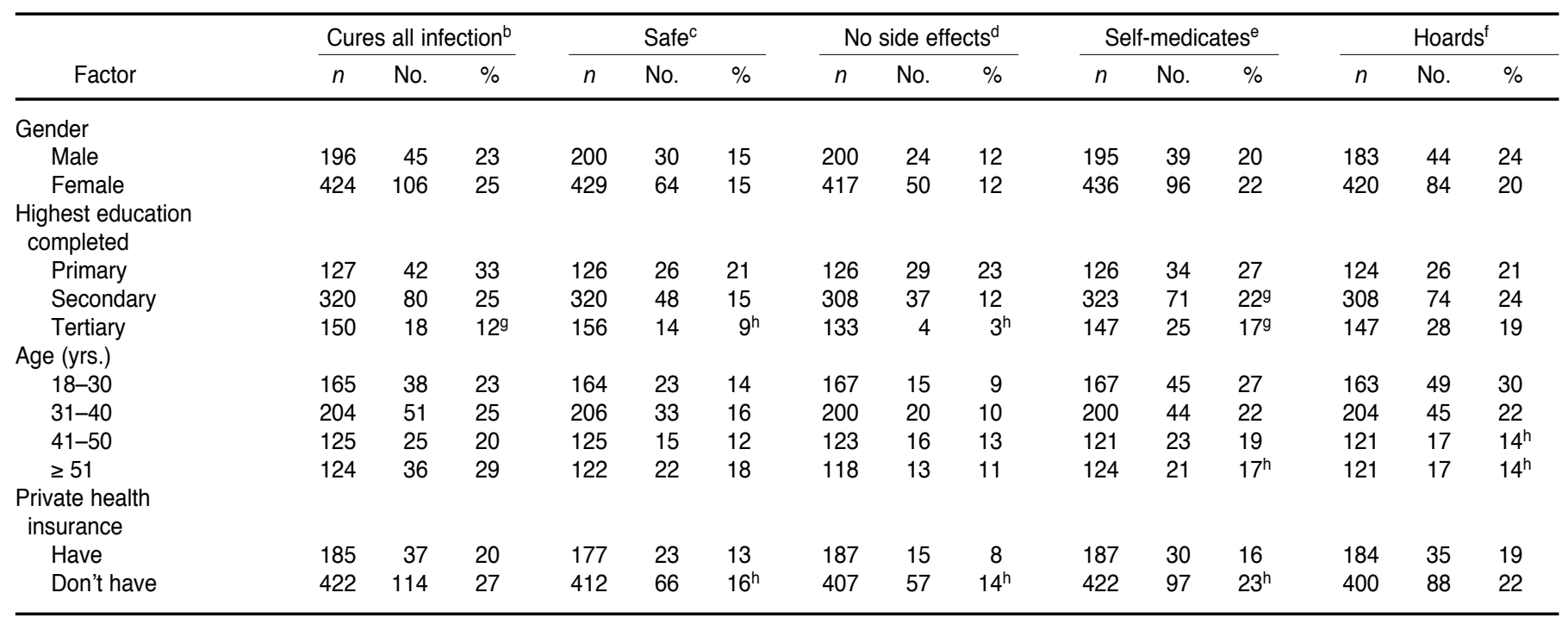

a The demographic variables are presented and analyzed for those respondents who answered "Yes" to the respective statement. Respondents who refused to answer or who gave no answer were excluded in this analysis. Thus, the totals in the respective groups (e.g., gender) differ from those in Table 1.

${ }^{b}$ Cures all infections $=$ respondents said that antibiotics cure all infections.

${ }^{c}$ Safe $=$ respondents said that antibiotics are safe.

${ }^{\mathrm{d}}$ No side effects $=$ respondents said that antibiotics are free from side effects.

e Self-medicates $=$ respondents said that they self-medicate, using antibiotics obtained from a private pharmacy without a doctor's prescription.

${ }^{\mathrm{f}}$ Hoards $=$ respondents said they store antibiotics at home for emergency use.

${ }^{g}$ Chi-square test $P<0.01$.

${ }^{\text {h }}$ Chi-square test $P<0.05$

gender, age, education, or insurance status. Those respondents for whom data were not available were excluded from the analysis.

Table 2 shows the demographic characteristics of respondents who saidcorrectly or incorrectly-that the drugs from the list that the interviewer provided were antibiotics. Significantly more respondents between 41 and 50 years old correctly identified penicillin as an antibiotic. Also, while a significantly higher proportion of the persons in the oldest age group $(\geq 51)$ correctly said Benadryl was not an antibiotic, this oldest age group was somewhat more likely than those 31- 50 years old to incorrectly classify aspirin and Tylenol as antibiotics. Subjects with tertiary education were more likely to correctly identify the antibiotics from among the various drugs presented in the list. In comparison to persons who had private health insurance, a significantly higher proportion of subjects without such insurance wrongly classified Benadryl and aspirin as antibiotics. Significantly more respondents with private health insurance accurately classified tetracycline as an antibiotic as compared with those who did not have the benefit of private health insurance.

Table 3 shows demographic details on respondents answering questions concerning knowledge and use of antibiotics. Gender was not significantly associated with knowledge of their safety, with self-medication, or with hoarding antibiotics. Tertiary education was significantly associated with correct knowledge of antibiotics regarding their safety, their ability to cure infections, and their having no side effects. Relatively more people without health insurance said antibiotics are free of side effects, as compared with persons who had health insurance.

Education was not a predictor of hoarding (Table 3). However, age was significantly associated with storing antibiotics at home, with older persons being less likely to keep antibiotics at home for emergency purposes. Self-medication was less likely to be undertaken by those with a secondary or tertiary education. Significantly more individuals without health insurance said they do self-medicate with antibiotics.

\section{DISCUSSION}

This is the first cross-sectional population-based study in the Englishspeaking Caribbean that has attempted to identify and examine perceptions and use of antibiotics in the general population. Just under one-third of the households surveyed said they had consumed antibiotics in the preceding year. Our findings concerning which antibiotics were used were similar to the results from several other countries $(8,14,15)$, where antibiotics were frequently used for fever, cough, upper respiratory tract infections (URTIs), 
and gastrointestinal infections. While some of those studies also reported sexually transmitted diseases (STDs) as a frequent reason for self-medication, none of the households we questioned volunteered STDs as a reason for selftreatment. We attribute this finding to broad public awareness in Trinidad and Tobago of the need for prompt and correct STD treatment and of possible disease complications. The country has had a vigorous public education campaign, which can be credited with the pattern of early patient presentation at the country's major STD clinic, where treatment is free.

We found that tertiary education was associated with correct knowledge and use of antibiotics. Similarly, in Kerala, a state in India that has that country's highest literacy level, antibiotic self-medication was least common among higher-income, moreeducated persons and also among those who had private medical insurance (16). Private health insurance requires a physician to sign that he or she has indeed prescribed the medication, and this procedure may likely have discouraged self-medication.

In Trinidad and Tobago, the expense and time needed for a consultation with a private physician could have prompted the purchase of antibiotics without a prescription. Other authors have expressed similar concerns, including with patients in the United States failing to consult with a doctor before using "leftover" antibiotics that they had (12). The public can be encouraged to misuse antibiotics through inappropriate prescribing by clinicians who try to avoid the cost of laboratory investigation, try to expedite speedy recovery by treating suspected bacterial infections, and try to assure patients that they are receiving potent medication.

We found it interesting that $17 \%$ of the persons in our study refused to answer whether they shared antibiotics with family members or friends. In addition, there was a noticeable number of participants who refused to answer some of the other survey questions. Given that other researchers (17) have found that patients are reluctant to confess they have taken antibiotics before seeking medical attention, it is highly probable that the proportions that we and other investigators have found for antibiotic use and for selfmedication are underestimates.

Self-medication with antibiotics can result from previous indiscriminate physician prescribing, particularly for respiratory tract infections. We have earlier reported that respiratory tract infection was the most frequent reason for antibiotic prescriptions by physicians in the English- and Dutch-speaking Caribbean (18). The same illness is responsible for antibiotic misuse worldwide (19).

In this study of Trinidad and Tobago, $25 \%$ of survey participants felt comfortable asking their doctor for a prescription (demand prescribing). This suggests that clinicians must take a share of responsibility for antibiotic misuse by the public.

In Trinidad and Tobago and elsewhere around the world, the purchase of antibiotics without physician consultation clearly points to the public not being adequately informed about inappropriate use of these medications. The Pharmacy Division of the Ministry of Health and the Pharmacy Board of Trinidad and Tobago enforce strict regulations whose violation invites punitive action. In spite of that, one in five of our respondents stated they obtained antibiotics as over-the-counter medications at private pharmacies, without a doctor's prescription. The respondents self-medicated for such things as cough, cold, and sore throat, all of which can be self-limiting with the appropriate medical and supportive care. Other researchers have reported that antibiotics can be obtained on demand from hospitals and pharmacies as well as from medically untrained vendors who sell these drugs in the marketplace or at roadside stalls, in regions that include Africa (14), Asia (20, 21), and Latin America (22).

From this situation, three key areas of concern emerge. One is the need for more stringent regulations, along with the establishment of surveillance systems to provide information on trends in bacterial resistance, which is essential for clinical practice. A second concern is continuous education for pharmacists and doctors on the consequences of inappropriate antibiotic use in the community. A third worry is the manner in which lay persons use antibiotics on their own initiative, suggesting education of the public is an important task in discouraging unnecessary use of antibiotics. These issues, along with enhanced pharmacy advice, better susceptibility data, and improved safety monitoring, have been discussed by the Working Party of the British Society for Antimicrobial Chemotherapy (13).

We took steps to avoid bias in collecting the data for our Trinidad and Tobago study. These measures included pilot-testing the evaluation instrument and training the interviewers to standardize their questioning. However, the study does have its limitations. For example, responses were dependent on patient recall and on the participants' complete understanding of the meanings conveyed in the questions. Since we used a telephone survey, the opportunity for detailed explanation was limited and reliance was placed on what the respondent understood. About $10 \%$ percent of the households in Trinidad and Tobago do not have telephone service, and some $15 \%$ of the Telecommunication Services customers have unlisted telephone numbers. The study excluded those two groups, who might have responded differently to the survey questions. In spite of these various limitations, we believe our results do provide a true reflection of how the general population of Trinidad and Tobago perceives and uses antibiotics.

Antibiotic use and misuse remains a complicated issue in developing countries, where the selection and spread of resistant organisms can be traced in part to socioeconomic, cultural, and behavioral influences (1). Physicians, pharmacists, retailers, drug suppliers, medical representatives, and even the mass media are inadvertent contributors to the misuse of antibiotics, by encouraging and supporting the general population's use of these drugs. As in 
the industrialized world, in the developing world education is the prime strategy to halt the continuing misuse of antibiotics, and this education needs to be targeted at consumers and all other relevant groups. The recommendations that the World Health Organization makes for drug use (23) should be adapted into country-specific antibiotic protocols to address the escalating spread of antibiotic resistance in developing countries.

Though supposedly prescriptiononly medications, antimicrobials in reality thrive in the open, unregulated market, making their audit and surveillance integral to solving the misuse problem. The misuse of antibiotics is a complex societal and health issue, for which doctors and pharmacists, unskilled practitioners, and the public must all take responsibility. Okeke and colleagues (24) have discussed these influences on inappropriate antibiotic use, which result in selective pressure favoring the emergence of resistant bacterial strains. These researchers also identify strategies to combat the problem of antibiotic resistance, particularly in developing tropical countries. Trinidad and Tobago, like other developing countries, does have unregulated antibiotic use and misuse, including overuse. Hart and Kariuki (3) have suggested such countries chart the progress and impact of bacterial resistance by improving access to diagnostic laboratories, improving surveillance of emergent bacterial resistance, improving regulation of antibiotic use, and instituting educational interventions for the public and for physicians and other health workers. Surveillance programs to examine antibiotic resistance in the community as well as policies to contain the emergence and spread of bacterial resistance should receive the urgent attention of the health authorities in Trinidad and Tobago and also the wider Caribbean region. We recommend communication efforts for health organizations, physicians, consumers, and pharmacists to improve their understanding of microorganisms, antimicrobial therapy, and antimicrobial resistance (25). Educating the medical profession on judicious prescribing is as vital as consumer education in addressing the inappropriate use of antimicrobials $(3,25)$. Disseminating evidenced-based data from national surveillance programs on the benefits of "no treatment" or "watchful waiting" will assist consumers in making informed choices on their treatment options. This could be done, for example, via posters and pamphlets in community health centers and through regular public service announcements and other mass-media efforts. Continuing education programs for health care professionals could also promote behavior change. These various measures should be evaluated on an ongoing basis and then modified and improved so as to contribute as much as possible to halting the burden of growing antibacterial resistance in Trinidad and Tobago.

Acknowledgements. We thank Mrs. Taylor, Mrs. V. Akal, and Mrs. W. Garcia of Bishop Anstey High School for their cooperation with and support for the study. The data collectors conducting the interviews were: A. Gomez, C. Caruth, N. Wynter-Roach, M. SueWinnifred, M. Lee, and L. Franklin. We also acknowledge the assistance of the Telecommunication Services of Trinidad and Tobago.

\section{REFERENCES}

1. Williams RJ, Heymann DL. Containment of antibiotic resistance. Science 1998;279:11531155.

2. Levy SB. Antimicrobial resistance: bacteria on the defence. BMJ 1998;317:612-613.

3. Hart CA, Kariuki S. Antimicrobial resistance in developing countries. BMJ 1998;317:647-650.

4. Kunin CM. Resistance to antimicrobial drugs: a worldwide calamity. Ann Intern Med 1993; 118:557-561.

5. Brown S, Warnnissorn T, Biddle J, Panikabutra K, Traisupa A. Antimicrobial resistance of Neisseria gonorrhoea in Bangkok: is single drug treatment passe? Lancet 1982;2(8312): 1366-1368.

6. Appelbaum PC, Bhamjee A, Scragg JN, Hallet AF, Bowen AJ, Cooper RC. Streptococcus pneumoniae resistant to penicillin and chloramphenicol. Lancet 1977;2(8046):995-997.

7. Sack RB, Rahman M, Yunus M, Khan EH. Antimicrobial resistance in organisms causing diarrheal disease. Clin Infect Dis 1997;24 Suppl 1:S102-105.

8. Bennish ML, Salam MA, Hossain MA, Myaux J, Khan EH, Chakraborty J, et al. Antimicro- bial resistance of Shigella isolates in Bangladesh, 1983-1990: increasing frequency of strains multiply resistance to ampicillin, trimethoprim-sulfamethoxazole, and nalidixic acid. Clin Infect Dis 1992;14:1055-1060.

9. Jones RN. Global aspects of antimicrobial resistance among key bacterial pathogens: results from the 1997-1999 SENTRY Antimicrobial Program. Diagn Microbial Infect Dis 1998; 32 Suppl 2:81-167.

10. Jones RN, Pfaller MA. Bacterial resistance: a worldwide problem. Diagn Microbial Infect Dis 1998;31:379-388.

11. Prabhakar $P$, Caribbean Antimicrobial Surveillance Group. Antimicrobial resistance in the Caribbean. West Indian Med J 2000;49 (Suppl 2):62.

12. Richman PB, Garra G, Eskin B, Nashed AH, Cody R. Oral antibiotic use without consulting a physician: a survey of ED patients. Am J Emerg Med 2001;19(1):57-60.

13. Reeves DS, Finch RG, Bax RP, Davey PG, Li Wan Po A, Lingam G, et al. Self-medication of antibacterials without prescription (also called 'over-the-counter' use). A report of a
Working Party of the British Society for Antimicrobial Chemotherapy. J Antimicrob Chemother 1999;44(2):163-177.

14. Obaseiki-Ebor EE, Akerele JO, Ebea PO. A survey of antibiotic outpatient prescribing and antibiotic self-medication. J Antimicrob Chemother 1987;20(5):759-763.

15. Sturm AW, van der Pol R, Smits AJ, van Hellemondt FM, Mouton SW, Jamil B, et al. Over-the-counter availability of antimicrobial agents, self-medication and patterns of resistance in Karachi, Pakistan. J Antimicrob Chemother 1997;39(4):543-547.

16. Saradamma RD, Higginbotham N, Nichter M. Social factors influencing the acquisition of antibiotics without prescription in Kerala State, South India. Soc Sci Med 2000;50(6): 891-903.

17. Catalano M, Almiron MA, Romeo AM, Caruso E, Murtagh P, Harisiadi J. Comparison between parental report and results of microbiologic agar assay for presence of antibiotic in urine of Argentinian children with acute lower respiratory tract infection. Rev Infect Dis 1990;12 Suppl 8:S998-1000. 
18. Pinto Pereira LM, Prabhakar P. A survey on antibiotic prescribing practices of physicians in the Caribbean. Caribbean Med J 1999; 61(S1):19-20.

19. Gonzales R, Sande M. What will it take to stop physicians from prescribing antibiotics in acute bronchitis? Lancet 1995;345(8951):665666.

20. Dua V, Kunin CM, White LV. The use of antimicrobial drugs in Nagpur, India. A window on medical care in a developing country. Soc Sci Med 1994;38:17-24.

21. Lansang MA, Lucas-Aquino R, Tupasi TE, Mina VS, Salazar LS, Joban N, et al. Purchase of antibiotics without prescription in Manila, the Philippines. Inappropriate choices and doses. J Clin Epidemiol 1990;43:61-67.

22. Wolff MJ. Use and misuse of antibiotics in Latin America. Clin Infect Dis 1993;17 Suppl 1:S346-S351.

23. Couper MR. Strategies for the rational use of antimicrobials. Clin Infect Dis 1997;24 Suppl 1:S154-S156.

24. Okeke IN, Lamikanra A, Edelman R. Socioeconomic and behavioral factors leading to acquired bacterial resistance to antibiotics in developing countries. Emerg Infect Dis 1999; 5(1):18-22.
25. Belongia EA, Schwartz B. Strategies for promoting judicious use of antibiotics by doctors and patients. BMJ 1998;317:668-671

Manuscript received 6 September 2001. Revised version accepted for publication on 22 February 2002.

RESUMEN Objetivo. Investigar las percepciones del público general y el uso de antimicrobianos en Trinidad y Tabago, una república caribeña formada por dos islas.

Métodos. En este estudio prospectivo se encuestaron, entre noviembre de 1998 y enero de 1999, 824 domicilios seleccionados aleatoriamente que figuraban en la lista telefónica. En las entrevistas, realizadas por teléfono, se investigaron los conocimientos sobre los antimicrobianos y las creencias de los entrevistados acerca de su eficacia y seguridad. Se estudió la influencia de la edad, del sexo, de la educación y del hecho de disponer de seguro de salud privado sobre los conocimientos, la automedicación, el almacenamiento de medicamentos en casa para utilizarlos en caso de urgencia ("acumulación") y la petición de prescripción de antimicrobianos a médicos privados ("demanda de prescripción").

Resultados. De los 824 contactos telefónicos realizados por los entrevistadores, en $753(91,4 \%)$ se obtuvo una respuesta favorable a la participación en la encuesta. De estos 753 participantes, 699 (93\%) conocían el término “antibióticos", 29\% (206/699) dijeron que se trataba de fármacos para las infecciones bacterianas, y 25\% (170/690) le habían pedido al médico prescripciones de antibióticos. La penicilina fue identificada correctamente como un antibiótico por personas de diferentes edades, sexos y niveles educacionales, pero el $36 \%$ de los entrevistados dijeron que el Benadryl (difenhidramina), un fármaco muy utilizado en el resfriado y que no necesita receta médica, era un antibiótico. El sexo no se asoció de forma significativa a los conocimientos sobre la seguridad de los antibióticos, a la automedicación ni a la "acumulación" de antibióticos. Por otra parte, el haber completado estudios universitarios se asoció de forma significativa a un buen conocimiento de la seguridad de los antibióticos y del hecho de que no curan todas las infecciones. Los beta-lactámicos fueron los antimicrobianos que los encuestados habían usado con mayor frecuencia el año anterior, período durante el cual el $20 \%$ de ellos habían usado múltiples antibióticos. En comparación con las personas que disponían de seguro de salud privado, las que no lo tenían afirmaron con más frecuencia que los antibióticos son seguros y no tienen efectos colaterales y que la aspirina y el Benadryl son antibióticos.

Conclusiones. En Trinidad y Tobago, el uso inapropiado de los antimicrobianos se debe a la automedicación, a la posibilidad de adquirirlos en las farmacias sin necesidad de receta médica, a la "demanda de prescripción" y a la ausencia de normas de control. Con el fin de reducir el abuso de antibióticos, la Inspección de Medicamentos del Ministerio de Salud y el Consejo de Farmacéuticos deben ejercer un control más estricto sobre la dispensación de antibióticos en las farmacias privadas. Además, se debe informar mejor al público en general y a los profesionales sanitarios acerca del uso de los antibióticos e instaurar un sistema basado en la comunidad para vigilar las tendencias de la resistencia a los antimicrobianos. 